\title{
Make a Match Learning Model Assisted with Picture Media Improve Students' Reading Skills
}

\author{
N. P. Feny Yuliawati \\ Primary School Teacher Education Teacher Education Study Program, FIP, Ganesha University of Education, Singaraja, Indonesia \\ Email: fenyyulia95@gmail.com
}

N. W. Rati
Primary School Teacher Education Teacher Education Study Program, FIP, Ganesha University of Education, Singaraja, Indonesia
Email: niwayan.rati@undiksha.ac.id

K. Suranata

Primary School Teacher Education Teacher Education Study Program, FIP, Ganesha University of Education, Singaraja, Indonesia

Email: kadek.suranata@undiksha.ac.id

A R T I C L E I N F O

\section{Article history:}

1 Maret 2020 Received in

revised form

30 Maret 2020

Accepted 11 April 2020

Available online 15

Mei 2020

\section{Kata Kunci:}

Keterampilan Membaca,

Make A Match, Media

Gambar

Keywords:

Reading Skills, Make A

Match, Picture Media

\begin{abstract}
A B S T R A K
Rata-rata hasil keterampilan membaca siswa di kelas II disebabkan karena tingginya aktifitas siswa yang cenderung suka bermain dan belum diterapkannya model pembelajaran yang relevan. Oleh karena itu, penelitian ini bertujuan untuk menganalisis pengaruh serta perbedaan keterampilan membaca siswa yang diakibatkan dari penerapan model pembelajaran kooperatif tipe Make A Match berbantuan media gambar. Jenis penelitian ini adalah penelitian pra-eksperimen dengan rancangan Static Group Comparison. Populasi penelitian berjumlah 98 orang siswa sedangkan sampel dalam penelitian ini berjumlah 39 orang siswa yang diambil dengan cara memilih secara acak dari semua populasi kelas yang ada sebagai intact group. Data keterampilan membaca siswa dikumpulkan menggunakan metode non tes (observasi). Data dianalisis menggunakan statistik deskriptif, statistik inferensial (Uji-t), dan Uji d Cohen. Berdasarkan hasil uji hipotesis didapatkan hasil bahwa terdapat perbedaan keterampilan membaca siswa ( $\mathrm{t}_{\text {hitung }}=14,60>\mathrm{t}_{\text {tabel }}=1,69$ pada taraf signifikansi $5 \%$ ), dan terdapat pengaruh model pembelajaran kooperatif tipe Make A Match berbantuan media gambar terhadap keterampilan membaca siswa $(\mathrm{d}=4,91>0,8)$, dengan demikian dapat disimpulkan bahwa model pembelajaran kooperatif tipe Make A Match berbantuan media gambar berpengaruh positif terhadap keterampilan membaca siswa.
\end{abstract}

\begin{abstract}
A B S T R A C T
The results reading skills of students in grade II is relatively low. That is due to the high activity of students who tend to like to play and have not applied the relevant learning method. Therefore, this study aims to analyze the effect and differences in students' reading skills resulting from the application of the Make a Match type of cooperative learning model assisted by picture media. The type of this study is pre-experimental research with a Static Group Comparison design. The study population was 98 students while the sample of this study was 39 students taken by the selection of all the population in each class as an intact group randomly. The data of the students reading skills were obtained using the non-test method (observation). Data were analyzed using descriptive statistics, inferential statistics (t-test), and Cohen's test. Based on the results of hypothesis testing obtained from the results of research on students 'reading difficulties (t-count $=14.60>\mathrm{t}$-table $=1.69$ at a significance level of 5\%), and there is a Make A Match type cooperative learning model that is assisted by image media to test students' reading skills $(\mathrm{d}=4.91>0.8)$, thus it can be concluded that the cooperative learning model of the type of Make A Match aided by media images has a positive effect on students' reading skills.
\end{abstract}

\section{Introduction}

Education is needed to improve the quality of human resources as well as ways to achieve the dream of the Indonesian nation to give birth to a smart and prosperous nation. Education provides great opportunities for someone to develop their potential (Miskawati, 2019; Wirasasmita \& Hendriawan, 2020) states that education is a structured way of structuring to mature someone. Education can be said to be successful if every element of education can carry out their respective roles well. To fulfill this, the goals of education must be achieved. Being a person who is obedient to religion, has a noble character, can fulfill his needs, is smart, and has skills that can later be useful for his life, the community in his environment, and for his nation is the main goal of education (Sujana, 2019). In this regard, learning activities must be carried out as much as possible so that they can produce quality output. 
Learning is an interaction in the learning environment that occurs between students and teachers, learning materials, learning methods, and strategies, and learning resources. Increasing learning outcomes is an expectation of a learning activity (Pane \& Darwis, 2017; Susanti, 2020). Improving learning outcomes is not only fixed on the assessment of learning outcomes on the cognitive aspects but must also be assessed on the affective and psychomotor aspects. In the world of education, special attention needs to be given, this is because the success of education is very dependent on the educational process itself. The teacher's duty as an educator is not just to transfer knowledge, but the teacher must also pay attention to how he provides knowledge by arousing the enthusiasm and creativity of students to learn.

Today's world of education is mostly marked by the academic achievement that is still standard. Many students have not been able to be skilled in realizing what they have learned. The learning process that makes the teacher the center of learning makes students less active (Belajar, Pada, \& Pelajaran, 2019; Krisdayati \& Kusmariyatni, 2020). This learning activity results in students being only seen as passive learning objects which if allowed to continue can reduce the quality of education. The problem that often occurs at this time is the lack of enthusiasm of students in participating in the learning process which results in a decrease in student learning outcomes. The existence of various kinds of learning models that have been proposed as solutions to previous studies aimed at improving student learning outcomes cannot be used as a guarantee in student learning success. This is because the learning process is always teacher-centered. This makes students lazy to learn and reluctant to learn, resulting in decreased student learning outcomes. Learning must foster an atmosphere in such a way that it can activate students and make students skilled to learn by questioning and expressing their opinions. This is certainly in accordance with the demands of the 2013 curriculum which requires students to be active and skilled in learning in all learning. One of the lessons that require students to be active and skilled in learning Indonesian.

Indonesian is learning that requires student skills which include reading skills. Skills are the means and / or expertise that students have in completing their obligations in learning activities so that meaningful learning outcomes are obtained (Yuliana, 2020). While reading is something that is interrelated with each other so that it must be studied to obtain knowledge and information contained in the contents of the reading, so that the more you read, the more you will be able to find out what has not been learned (Krisdayati \& Kusmariyatni, 2020; Tiswardini, 2019). Based on these two opinions, it can be concluded that reading skills are the means and or skills that students have in completing their obligations in learning activities so that knowledge and information can be obtained that can provide students with meaningful learning outcomes.

Reading is an activity to understand written language. In reading activities, there are several types of reading, which include reading silently and reading aloud. Silent reading is an activity to read silently. Silent reading is reading without making a sound, no movement of the lips and head, not whispering, deepening the reading material, reading the eye speed of 3 words / second, liking reading material, and being able to align the difficulty level of the reading material (Cahyaningsih, 2019). Silent reading is also said to be a reading activity carried out without the slightest sound, by reading can translate, interpret symbols in a language that the reader understands (Caloyeras et al., 2014; Salma \& Mudzanatun, 2019). Based on these two opinions, it is concluded that silent reading is a reading activity that requires a high level of concentration. also stated, This is because the silent reading activity does not allow students to make a sound, moreover students are not allowed to move their lips, head, or point at writing while reading and reading speed is 3 words/second so that students can align the difficulty level that exists in reading material.

In silent reading, in addition to being required to have a high level of concentration, students are also required to have good visual acuity and memory. This is because students can master the content of the reading appropriately. Silent reading is divided into 1) extensive reading, namely reading activities broadly, the broad target object, 2) intensive reading, which is a reading activity that requires understanding and study of a higher reading, 3) scanning reading is one type of reading that is done quickly and right on target, 4) speed reading is a reading activity that relies on the speed of eye movement (Romlah, 2019). In the initial reading phase, especially for low-grade students, reading aloud is more required, this is because reading aloud is a reading activity carried out by making a loud sound. Reading aloud is reading using a fairly loud intonation (Marya et al., 2017). Reading aloud is also said to be an activity of reading aloud which is carried out by voicing writing balanced with the speed of the eyes and sound of at least 3 words/second so that more thorough skills are needed (Lailan et al., 2020). Based on these two opinions, it can be concluded that reading aloud is a reading activity through voicing the writing of reading material which is carried out by voicing the writing balanced with the speed of the eyes and the sound of at least 3 words/second so that more comprehensive skills are needed.

In reading aloud, students are required to bes able to master several existing skills. According to Barbeang Abbott and Dawson (in Cici Marantika, 2019) The skills required in reading aloud, namely (1) class I include the skills to use appropriate speech, intonation, and phrases and master simple punctuation signs, (2) class II includes reading skills clearly and clearly, full of feeling or expression and reading without 
stammering/stammering, (3) class III includes reading skills with feeling or expression and understanding and understanding the content of the reading, (4) class IV includes skills to understand the reading content at the basic level and being able to use eye and voice speed (at least 3 words/second), (5) class $\mathrm{V}$ includes reading skills with understanding, reading with feeling, and being able to read without constantly looking at the reading material, (6) grade VI includes reading aloud with feelings or expressions, read confidently and use the correct phrases or wording. In improving reading skills, there are four phases of a reading program that a person must go through. The four phases/stages according to Steinberg (Anggraeni et al., 2016) namely the phase of recognizing words, the stage of recognizing words, the stage of recognizing phrases and sentences, and the stage of reading paragraphs and books. The word recognition stage aims to introduce students to the forms and differences between spoken words and written words. The word recognition stage aims to teach students how to pronounce words and their meanings. The phase to recognize phrases and sentences aims to teach students how to pronounce phrases and sentences and their meanings. The paragraph or book reading stage aims to teach students to read and understand what is read in a paragraph or book. In the implementation of teaching reading, the teacher must provide guidance as much and as effectively as possible for students to be skilled in reading.

Effective learning activities require a learning model that is adapted to the conditions of students. The existence of a learning model can make it easier for teachers to deliver teaching material and can provide more meaningful learning to students so that it can improve student learning outcomes. This is because the application of the learning model is one of the most important factors that can influence student learning outcomes (Larasati, Susongko, \& Isnani, 2017; Putri \& et al., 2018). The learning model will run effectively if it is supported by supporting media in learning activities. Good learning media is learning media that can make it easy for students to understand the subject matter, a pleasant atmosphere for student learning, and can attract students' attention. Learning media is a learning component that can be used to convey information so that information can be digested easily so that it is useful in learning activities (Mawardi, Iriani, \& Daryati, 2019; Nida \& et al., 2020). By using the media, communication activities in learning activities can be done easily and are more active for students.

Based on the results of observations made on grade II students at SD Gugus VI, Gianyar District, Gianyar Regency, 2019/2020 academic year on October 19, 2019, the results showed that Indonesian language learning related to students' reading skills was not in line with expectations. This is indicated by the average student is less able to do pronunciation well, the way students read is still halting, and in reading students tend to pay less attention to punctuation marks. Some of these problems have an impact on student learning outcomes. This is reinforced by the results of recording documents through data collection activities, namely the achievement of student learning outcomes in the Middle Semester Assessment (PTS) of a student's Indonesian language lesson content which is still low. The PTS 1 student score data is presented in Table 1 below.

Table 1. Data of PTS 1 Value in Indonesian for Elementary School Cluster VI Students

\begin{tabular}{lccccc}
\hline \multirow{2}{*}{ School Name } & Passing & Average & Total & \multicolumn{2}{c}{ Total } \\
\cline { 5 - 6 } & Grade & value & students & Completed & Not Competed \\
\hline SD Negeri 1 Tulikup & 65 & 64.20 & 10 & 6 & 4 \\
SD Negeri 2 Tulikup & 65 & 62.78 & 23 & 8 & 15 \\
SD Negeri 3 Tulikup & 75 & 68.88 & 26 & 12 & 14 \\
SD Negeri 4 Tulikup & 70 & 65.38 & 21 & 7 & 14 \\
SD Negeri 5 Tulikup & 65 & 61.33 & 18 & 8 & 10 \\
\hline Total & & & $\mathbf{9 8}$ & $\mathbf{4 1}$ & $\mathbf{5 7}$ \\
\hline
\end{tabular}

(Source: Guardian Class II in Cluster VI, Kec. Gianyar, Kab. Gianyar)

In addition to the observations, the results of interviews were also obtained, namely that some of the above-average problems were influenced by three factors: first, parents 'busyness greatly influenced students' reading skills. This is due to the lack of learning guidance and motivation provided by the parents of students, which affects students' reading skills. Children at the elementary level still really need the motivation and real support that parents need to provide to realize children's passions, especially in the field of reading (Nafotira, 2018). Based on this opinion, it can be concluded that the role of parents in providing motivation and support to children is very important for their learning success, especially in reading skills. Second, the activities of students who tend to like to play affect students' reading skills. Students become unfocused in learning because students always want to play. This causes students to be less skilled in reading. Third, the relevant learning model has not been implemented in improving students' reading skills in Indonesian language subject matter. 
This is due to the habit of teachers applying the lecture method to students, which causes students' abilities to be less. Based on the above problems, in the learning process, it is necessary to innovate or change the way of thinking related to students' reading skills. Many learning models can be applied to support the achievement of increasing student learning outcomes, especially Indonesian related to reading skills, one of which is the Make A Match type of cooperative learning model.

The Make A Match learning model is a cooperative learning model, namely by playing matching cards. The cooperative learning model is a learning model that focuses students on learning in small groups to create good cooperation between students (Anika \& Fajar, 2020; Komala \& Asri, 2018). Shomin (in Maryam \& Sukmana, 2019) The Make A Match learning model is a cooperative learning model, namely by playing matching cards. The cooperative learning model is a learning model that focuses students on learning in small groups to create good cooperation between students (Lestari \& Muhajir, 2019). Based on these opinions, it can be concluded that the Make a Match type of cooperative learning model is a learning model that involves students learning happily which is done by playing to find pairs of question cards and answers related to a topic being studied. This is of course very suitable for the conditions of elementary school students who tend to like to play. Huda (i Maharani \& Kristin, 2017) states that there are several syntaxes of the Make a Match type of cooperative learning model, namely: 1) The teacher provides the material; 2) Students are divided into two; 3 ) distribution of question cards to group one and distribution of answer cards to group 2;4) the students match the pair cards within the predetermined time limit; 5) the teacher gives instructions regarding the time when it is up; 6) students present the results of the matched pairs of cards; 7) teacher confirmation regarding whether or not the student's work is correct; 8) repeated shuffling of cards. Research conducted by Olivia, et al., (2019) states that there are several syntaxes of the Make a Match type of cooperative learning model, namely: 1) The teacher provides the material; 2) Students are divided into two; 3) distribution of question cards to group one and distribution of answer cards to group 2;4) the students match the pair cards within the predetermined time limit; 5) the teacher gives instructions regarding the time when it is up; 6) students present the results of the matched pairs of cards; 7) teacher confirmation regarding whether or not the student's work is correct; 8) repeated shuffling of cards. Research conducted by Anika \& Fajar (2020) stated that Make a Match learning model can improve student learning outcomes by about $85 \%$. This is because students are more enthusiastic about participating in learning so that it fosters an attitude of cooperation and trains student concentration in learning.

A Match uses image media as a means of supporting student learning activities. Image media is a type of visual media in the form of graphics. Visual media are all props that students can enjoy through their eyesight so that students can remember longer by making it easier for teachers to convey information (Nida \& et al., 2020; Visual, 2012). Several studies also support this statement; one of these studies is Anriyani's (2019) research which obtained positive results from the application of image media to improve essay writing skills. Besides, in the learning process, image media is the most widely used. This is because the acquisition of image media is very easy. Image media can display material visually by taking pictures from relevant sources according to the subject matter (Yuswanti, 2019). Image media can be a tool that helps the learning process because it can clarify understanding to students (Eferi, 2017). Image media can concretize abstract things, making it easier for students to absorb information. The advantages of image media are: 1) image media are concrete in nature, 2) images can help students see events at different locations and times, 3) can minimize students' limited vision, 4) mambu images provide clarity regarding the material being studied, 5 ) the price of the image is very economical and easy to obtain (Puspitowati, 2019). Supporting research conducted by Yuswanti (2019) states that the increase in student learning outcomes after applying image media in learning. This is because students are more motivated and interested in learning when using image media. Students find it easier to understand the material through image media (Saputro, 2019) states that image media can increase students' enthusiasm for learning so that it affects improving student learning outcomes. Based on this research, it can be concluded that image media can increase student motivation and learning outcomes.

The application of the Make A Match type of cooperative learning model assisted by picture media will be able to make it easier for teachers to improve students' reading skills, this is because the Make A Match type of cooperative learning model has a positive impact on students in the learning process. This is supported by the results of research conducted by (Ramadhan et al., 2019) which states that the Make a Match learning model can improve student mathematics learning outcomes. Then research conducted by (Kasminah et al., 2019) which states that the application of the Make A Match learning model can improve student Pkn learning outcomes, research conducted by (Krisdayanti et al., 2020) with the results of the study that the Make A Match learning model can increase reading interest students. (Anggraeni's research, 2019) states that the application of the Make A Match learning model can increase student motivation. Other supporting research by (Riyanti \& Nisrohah, 2018) which states that the application of the Make a Match type of cooperative learning model can foster the curiosity of students about the questions and answers given by the teacher. Students feel interested in the material provided and are interested in solving existing problems. Research conducted by (Tiballa et al., 
2017) states that the Make a Match type of cooperative learning model can improve student learning outcomes. This is because the Make a Match type of cooperative learning model can create an active and fun learning atmosphere so that it can attract students' attention.

Based on the explanation above, the research objectives were formulated, namely to analyze the influence and differences in students' reading skills resulting from the application of the Make a Match type of cooperative learning model assisted by image media. In this study, the cooperative learning model of the Make a Match type will be combined with the image media according to the Indonesian language material. The steps to be applied are in accordance with the syntax of the Make a Match type of cooperative learning model. The Make a Match cooperative model is applied in steps, namely the first stage the teacher prepares the card according to the learning topic. Then the student who gets the card thinks about the answer, and the student looks for the pair who has the card according to the answer. In the last stage, the teacher provides conclusions from the learning material. There is a difference between the current research and previous research, namely the use of image media in the application of the Make A Match cooperative learning model in improving students' reading skills. With the application of the Make a Match type of cooperative learning model, it is hoped that it can improve students' reading skills.

\section{Method}

This study used an experimental method with a pre-experimental research type. The design of this study followed a pre-experimental basic pattern with a Static Group Comparison design. The research design can be seen in Table 2 below.

Table 2. Research Design Static Group Comparison

\begin{tabular}{ccc}
\hline Treatment & Target \\
\hline $\mathrm{X}$ & $\mathrm{O} 1$ & $\mathrm{O} 2$ \\
-- & &
\end{tabular}

(Dantes, 2017:14)

Description:

O1: post-test experimental group

$\mathrm{O} 2$ : post-test control/comparison group

$\mathrm{X}$ : treatment as the independent variable

This design consists of two groups of subjects, namely the control group and the experimental group. The treatment was given to the experimental group only and data collection was carried out on both groups. In the control group, the Make A Match type of cooperative learning model assisted with image media was not applied, while in the experimental group the Make A Match type of cooperative learning model was applied with the assistance of image media. Both groups were not given a pre-test, after being subjected to treatment, they were measured (post-test). The whole class II SD students in Cluster VI, Gianyar District, Gianyar Regency in the 2019/2020 school year became the population in this study. The population number is presented in Table 3 below.

Table 3. Research Population Data

\begin{tabular}{cccc}
\hline No. & School Name & Grade & Total students \\
\hline 1. & SD Negeri 1 Tulikup & II & 10 \\
2. & SD Negeri 2 Tulikup & II & 23 \\
3. & SD Negeri 3 Tulikup & II & 26 \\
4. & SD Negeri 4 Tulikup & II & 21 \\
5. & SD Negeri 5 Tulikup & II & 18 \\
\hline \multicolumn{7}{c}{ Total Population } & $\mathbf{5}$ Class & $\mathbf{9 8}$ \\
\hline
\end{tabular}

In this study, the sample was drawn by randomly selecting all class populations as the intact group. At first, 2 classes were randomly selected as the research sample, then from the 2 classes were randomized again to obtain a control class and an experimental class. The selected class, namely class II SDN 4 Tulikup totaling 21 students as the experimental class and class II SDN 5 Tulikup totaling 18 students as the control class. 
The research data were then collected using the observation method. The observation method is one of the non-test methods that is widely used to collect data related to the evaluation of a behavior or a skill. In this study, data were obtained through direct observation by researchers of the object of research. The data needed is the result of students' reading skills. In evaluating students' reading skills, instruments in the form of observation sheets and assessment rubrics were used. Before the instrument is used, an expert test is carried out on two experts to obtain a quality instrument level. Furthermore, the instrument was tested in the field to determine the validity of the items and the reliability of the instrument. The item validity test was carried out using the product-moment correlation technique and the reliability test used the alpha Cronbach formula because the data was in the form of a polytomy. The preparation of the observation sheet for students' reading skills in this study used 7 aspects which are presented in Table 4 below.

Table 4. Aspects of Student Reading Skills

\begin{tabular}{ccc}
\hline Variable & No. & Aspects \\
\hline Reading Skills & 1. & Clarity of speech \\
& 2. & Use of phrases \\
& 3. & Voice intonation \\
& 4. & Simple punctuation mastery \\
& 5. & Reading clarity \\
& 6. & Expression \\
\hline
\end{tabular}

(Source: Barbeang Abbott and Dawson (in Cici Marantika, 2019))

Based on the results of expert testing, from the 7 points used, 2 invalid aspects were obtained so that in this study only 5 aspects of students' reading skills were used. Meanwhile, based on field trials to 32 students, the validity of the five aspects was declared valid and the results of the calculation of the reliability test were in the high category.

The results of the study were analyzed in stages, using descriptive statistical analysis and inferential statistics. Descriptive statistics were performed to describe in general about the distribution of data by looking for M, Md, Mo, and Sd. Inferential statistics were performed to test the hypothesis using Cohen's t-test and d test. The prerequisite test was carried out before testing the hypothesis to find out the data were normally distributed and homogeneous. The requirements test is done by using the data distribution normality test and the variance homogeneity test. The t-test is used to determine the differences in the reading skills of students while the Cohen $d$ test is used to reinforce the conclusions obtained in the hypothesis test using the t-test through the effect size so that it can be seen how much influence the given model has on the experiment carried out.

As for the hypothesis of this study, namely 1) there are differences in students' reading skills between students who learn with the Make A Match type of cooperative learning model assisted by picture media and students who are not taught with the Make A Match type of cooperative learning model assisted by image media in Indonesian class II lesson content. SD Gugus VI, Gianyar District, Gianyar Regency, 2019/2020 academic year, 2) there is an influence of the Make A Match type of cooperative learning model assisted by image media on students' reading skills in class II Indonesian language content of SD Gugus VI, Gianyar District, Gianyar Regency in the 2019 school year / 2020. In testing hypothesis 1, the t-test analysis was used at a significance level of 5\%, while the second hypothesis testing was carried out using Cohen's d test.

\section{Result and Discussion}

The target of this study is students' reading skills as a result of the treatment between the application of the Make A Match type of cooperative learning model assisted by image media and the non-application of the Make A Match type of cooperative learning model assisted by image media. Two things are the focus of this research, namely: 1) the difference in reading skills between students who learn with the Make A Match type of cooperative learning model assisted by image media and students who are not taught with the cooperative learning model of the Make A Match type assisted by image media, 2 ) the effect of the Make A Match type of cooperative learning model assisted by image media on students' reading skills. A summary of the results of the descriptive statistical analysis is presented in Table 5 below. 
Table 5. The summary of the results of the descriptive statistical analysis

\begin{tabular}{lcc}
\hline Statistics Variable & Y1 & Y2 \\
\hline $\mathrm{N}$ & 21 & 18 \\
Mean & 86,6 & 55,5 \\
Median & 88 & 54,3 \\
Modus & 89,85 & 54,1 \\
Standard Deviation & 5,85 & 6,78 \\
\hline
\end{tabular}

Referring to the results of descriptive statistical analysis of the data, it can be seen that the results of students 'reading skills in the experimental class, namely students who were taught with the Make A Match type of cooperative learning model assisted by image media were better than the results of students' reading skills in the control class, namely students who were not taught the learning model. cooperative type Make A Match assisted by image media. This is supported by the average reading skills of students in the experimental class which is 86.6 and the average reading skills of students in the control class are 55.5. After obtaining the results of the descriptive analysis of the data, the prerequisite test was then carried out which included the normality test of the data distribution and the homogeneity test.

In the research conducted, the distribution normality test was analyzed using the Chi-Square at the 5\% significance level with ethical testing if the price $\mathrm{X}^{2}$ hitung $<\mathrm{X}^{2}$ tabelthen the data distribution is categorized as normally distributed. The next step is to test the variance homogeneity. To test the variance homogeneity, the $\mathrm{F}$ test was used with homogeneous data ethics ifFhitung < Ftabel. The results of the calculation of the normality test of the data distribution and the homogeneity test of variance in this study are presented in Table 6 below.

Table 6. Normality Test and Homogeneity Test

\begin{tabular}{|c|c|c|c|c|c|c|c|}
\hline \multicolumn{5}{|c|}{ Normality Test } & \multicolumn{3}{|c|}{ Homogeneity Test } \\
\hline No & Sample & $\mathbf{X}^{2}$-count & $\mathrm{X}^{2}$-table & Ket. & $\mathbf{F}_{\text {-hit }}$ & $\begin{array}{l}\text { F-table with a } \\
\text { significance } \\
\text { level of } 5 \% \\
\end{array}$ & Status \\
\hline 1 & $\begin{array}{l}\text { Experiment } \\
\text { Class }\end{array}$ & 2,26 & 11,07 & $\begin{array}{l}\text { Distribution of } \\
\text { distributed data } \\
\text { Normal }\end{array}$ & 1,14 & 4,10 & Homogeneous \\
\hline 2 & Control Class & 1,80 & 11,07 & $\begin{array}{l}\text { Data } \\
\text { distribution } \\
\text { is normally } \\
\text { distributed }\end{array}$ & & & \\
\hline
\end{tabular}

Based on the results of the calculations in Table 6, it is known that the results of the data distribution normality test, namely the X2-count for the experimental class and the control class are smaller than the X2table price, so it can be concluded that all data has been normally distributed. The results of the calculation of the variance homogeneity test, namely the F-count of the reading skills of the experimental class and the control class, is 1.14. Meanwhile, F-table with the denominator $=21-1=20$, the db-denominator $=18-1=17$, and the 5\% significance level is 4.10 . These results show Fhitung < Ftabel $(4,51<4,10)$ so that the data variance of the reading skills of the experimental group and the control group is homogeneous. After the prerequisite test was carried out, the hypothesis was tested using the t-test. The results of the analysis using the t-test are presented in Table 7 below.

Table 7. Result of t-test analysis

\begin{tabular}{cccccl}
\hline No & Sample & Variants & t-count & t-table & Conclusion \\
\hline 1 & Experiment Group & 44,80 & \multirow{2}{*}{14,60} & \multirow{2}{*}{1,69} & $\begin{array}{l}\mathrm{t}_{\text {-count }}>\mathrm{t}_{\text {-table, so that H1 is }} \\
\text { accepted }\end{array}$ \\
\hline
\end{tabular}

Based on the results of the analysis in table 7, it was found that the t-count price was 14.60. Furthermore, the $\mathrm{t}$-count is compared with the $\mathrm{t}$-table value at the $5 \%$ significance level with $\mathrm{dk}=\mathrm{n} 1+\mathrm{n} 2-2=$ 
37 amounting to 1.69 . These results indicate that $\mathrm{t}$-count> $\mathrm{t}$-table so that $\mathrm{H} 0$ is rejected and $\mathrm{H} 1$ is approved. After the t-test is carried out, Cohen's d test analysis is carried out through the effect size to reinforce the conclusions obtained in the hypothesis test so that it is known how much influence the given model has on the experiment carried out. The effect size criteria are:1) $0<d \leq 0,2=$ efek kecil, 2) $0<\mathrm{d} \leq 0,5=$ efek sedang, 3) $0<\mathrm{d} \leq 0,8=$ efek besar, 4) $\mathrm{d}>0,8=$ efek efek sangat besar. The results of the analysis using Cohen's $d$ test are presented in Table 8 below.

Table 8. Results of Cohen's d Test Analysis

\begin{tabular}{ccccccc}
\hline No & Sample & Variants & N & D & $\begin{array}{c}\text { Comparison } \\
\text { criteria }\end{array}$ & Category \\
\hline 1 & Experiment Group & 44,80 & 21 & 4,91 & $\mathrm{~d}>0,8$ & $\begin{array}{c}\text { The effect is } \\
\text { huge }\end{array}$ \\
\hline
\end{tabular}

Based on calculations that have been done using the cohen test, the effect size is 4.91, so it belongs to the very large effect category. Hypothesis test results show: first, the results of the hypothesis using the t-test, namely $\mathrm{t}_{\text {-count }}>\mathrm{t}_{\text {-table }}$ with $\mathrm{t}_{\text {-count }}$ of 14.60 and $\mathrm{t}_{\text {-table }} 1.69$ which means that $\mathrm{H} 0$ is rejected and $\mathrm{H} 1$ is accepted. This means that there are differences in students' reading skills between students who learn with the learning model Cooperative Make A Match type is assisted by image media and students who are not taught with the Make A Match type of cooperative learning model assisted by image media in Indonesian language lesson content in class II SD Gugus VI, Gianyar District, Gianyar Regency in the 2019/2020 academic year. The results of the reading skills of the experimental class students were better when compared to the results of reading skills in the control class, this was due to the Make A Match type of cooperative learning model assisted by image media which was able to attract students' interest and attention so that students became active learning objects. The Make A Match type of cooperative learning model is a learning model that involves learning activities through playing activities on students, namely playing for pairs of cards to make students happy. In childhood, they tend to like playing activities and interacting with how to play (Nida et al., 2020; Umbara, 2020). Students who are invited to learn while playing will create maximum enthusiasm for learning. This is supported by the views of Suprijono (in Ubaidah, 2016) which revealed that the Make A Match type of cooperative learning model has the advantage of being able to arouse student activity and enthusiasm, besides that, the application of the Make A Match type of cooperative learning model can avoid student burnout due to learning activities while playing. Based on the above opinion, it can be concluded that the Make A Match type of cooperative learning model is very suitable to be applied to elementary level students considering the tendency of elementary school students to like to play.

Second, the results of Cohen's d test also show that the effect size of the research data is very high, with a value of $d=4.91$ so that $d>0.8$. This means that there is an influence of the Make A Match type of cooperative learning model assisted by image media on students' reading skills in Indonesian language lesson content for class II SD Gugus VI, Gianyar District, Gianyar Regency, 2019/2020 academic year. In Indonesian lessons, all student activities cannot be separated from reading activities. For elementary students who are skilled in reading is the main asset that students must have to be able to move to the next level so that teacher guidance in reading is very necessary to improve students' reading skills. This is supported by Heruman's view (in Widodo \& Kartikasari, 2017) who argues that guidance activities are very important because some theoretical material that must be digested by students must be given confirmation as soon as possible so that they can be remembered for a long time in the memory of students so that they can be realized properly by students. In the application of the Make A Match type of cooperative learning model with image media, students are guided through information mining activities when the learning process is carried out with the help of image media. Children at the elementary level are still at the concrete operational thinking stage. Each stage of a child's development has different characteristics (Rohaeti, Ramadan, \& Fitriani, 2019). At the concrete operational thinking stage, the child will better understand information if something concrete is presented so that, in the application of the Make A Match type of cooperative learning model, image media assistance is used as a learning tool for students. Image media is a visual media that can attract the attention of students in their learning activities. The advantages of image media are (1) image media is real, (2) image media can help students understand the material that is limited by location and time, (3) image media can minimize students' limited vision, (4) the media can provide a clear picture of a problem. Some of the advantages of the image media can support student learning activities so that students can get the real meaning of learning (Puspitowati, 2019; Umbara, 2020).

Third, the results of the application of the Make A Match type of cooperative learning model assisted by image media make students more active and quickly understand the lessons that are being learned, students 
also look very happy and enthusiastic in the learning activity process, different from students in the control class who do not apply the model Cooperative learning of the Make A Match type is assisted by picture media, students look quickly bored and bored, causing the lack of enthusiasm for student learning, considering that learning activities are only teacher-centered. In the experimental class, students are invited to learn while playing, this situation makes students in the experimental class superior to the control class. Learning activities while playing are the main characteristics of implementing a thematic-based curriculum that can increase students' knowledge quickly (Roti, 2020). This is because the activities carried out prioritize student fun so that students participate in learning with joy (Khoiron \& Rezania, 2020; Nida, et al., 2020) also revealed that learning activities while playing can increase the enthusiasm of students so that students have high motivation to learn. This difference can have a different effect on the results of reading skills, namely the results of the reading skills of students who learn without using the Make A Match type of cooperative learning model assisted by image media are lower than students who are taught with the cooperative learning model of the Make A Match type assisted by image media. This review is based on the difference in the mean scores of reading skills results between the experimental class and the control class. So, it can be concluded that the Make A Match type of cooperative learning model assisted by image media has a positive effect on the reading skills of grade II students of SDN 4 Tulikup, Gianyar District, Gianyar Regency, Academic Year 2019/2020. This statement is in line with the findings of research by (Pertiwi, 2018) which states that the Make A Match type of cooperative learning model affects students' reading and writing abilities, students become more enthusiastic to learn and practice reading and writing skills so that learning objectives can be achieved optimally. Tiballa and Masa (2016) also state that the Make A Match type of cooperative learning model affects student learning outcomes, students become active and quickly understand the material being studied so that there is an increase in student learning outcomes. Likewise, research by (Adnyana, 2017) obtained results that the application of image media was able to improve students' initial reading skills, students became focused on the media shown so that positive student responses could be created. This is supported by research conducted by (Tiballa et al., 2017) which states that the Make A Match type of cooperative learning model with different images and color media can attract students' attention in learning.

Based on the results of the research and discussion that has been explained, the practical implications of this research are for students when the Make A Match type of cooperative learning model assisted by image media is applied, students become very enthusiastic and active when participating in learning besides that with the help of image media it can attract attention students so that in the learning process, especially when reading students become more focused. In this regard, it is hoped that in the future students can maintain their enthusiasm and activeness in the learning process in the classroom, especially during reading activities. Furthermore, the implication for teachers is the application of the Make A Match type of cooperative learning model assisted by image media to make teachers more enthusiastic in teaching. Each teacher teaches the teacher to be challenged to make the classroom atmosphere fun. Also, the implementation of the Make A Match type of cooperative learning model assisted by image media provides opportunities for teachers to develop their teaching abilities so that they can improve students' reading skills.

To support the implementation of the Make A Match cooperative learning model, it is hoped that the teacher can continue to improve the quality of learning, that is, apart from being able to do it with the help of image media, teachers can use other media that are considered relevant in supporting learning so that they can improve student learning outcomes, especially in the field of reading. Likewise for school principals, the implementation of the Make A Match type of cooperative learning model assisted by image media can provide additional knowledge related to innovative learning models so that the principal can provide policies related to the availability of teaching and learning facilities. In connection with this, it is hoped that the principal can further improve the quality of education in the implementation of learning in schools so that educational goals can be achieved optimally.

\section{Conclusion}

Referring to the results of hypothesis testing and discussion, it can be concluded that there are influences and differences in students' reading skills resulting from the application of the Make A Match type of cooperative learning model assisted by image media. Make A Match assisted by the applied image media can increase enthusiasm and activities when participating in learning, besides that it can attract students' attention so that in the learning process, especially when reading, students become more focused. 


\section{References}

Anggraeni, K., Majalengka, U., \& Book, B. (2015). Efektivitas Metode Steinberg Dengan Media Big Book. 8394.

Anika, \& Fajar. (2020). Efektivitas Model Pembelajaran Kooperatif Tipe Make-A Match Dalam Meningkatkan Kompetensi Sikap Siswa dan Kompetensi Pengetahuan Siswa Pada Pelajaran IPS. Jurnal Ilmiah Sekolah Dasar, 4(1), 80-85.

Belajar, H., Pada, S., \& Pelajaran, M. (2019). 1 , 2 3. 8(2).

Caloyeras, J. P., Liu, H., Exum, E., Broderick, M., \& Mattke, S. (2014). Managing manifest diseases, but not health risks, saved PepsiCo money over seven years. Health Affairs, 33(1), 124-131. https://doi.org/10.1377/hlthaff.2013.0625

Cici Marantika. (2019). Pengaruh Buku Cerita Bergambar Terhadap Keterampilan Membaca Nyaring Peserta Didik Kelas III Min 7 Bandar Lampung. Jurnal Pendidikan, 78. https://doi.org/10.1017/CBO9781107415324.004

Eferi, Y. (2017). Media Gambar untuk Meningkatkan Proses dan Hasil Belajar Siswa pada Pembelajaran PKN. Jurnal Penelitian Pendidikan Indonesia, 1(3), 59-67.

Khoiron, M., \& Rezania, V. (2020). Studi Literatur Tentang Pengaruh Penggunaan Media. 6-7.

Komala, \& Asri, C. (2018). P2M STKIP Siliwangi P2M STKIP Siliwangi. Jurnal Ilmiah P2M STKIP Siliwangi P2M STKIP Siliwangi, 5(2), 1-6.

Krisdayati, \& Kusmariyatni. (2020). Model Pembelajaran Kooperatif Tipe Make A Match terhadap Minat Baca. Mimbar PGSD Undiksha, 8(2), 156-159. Retrieved from https://ejournal.undiksha.ac.id/index.php/JJPGSD/article/view/24935/15605

Lailan, E., Lubis, S., Lubis, R. R., Andriani, S., Studi, P., \& Bahasa, P. (2020). Pembelajaran membaca terbimbing dalam membantu kesulitan siswa membaca nyaring. 2(04), 1-9.

Larasati, N., Susongko, P., \& Isnani. (2017). Model Pembelajaran Problem Based Learning dengan Metode Discovery Learning terhadap Aktivitas dan Hasil Belajar Siswa. Jurnal Pendidikan MIPA Pancasakti, l(1), 35-42.

Maharani, O. D. tri, \& Kristin, F. (2017). Peningkatan Keaktifan dan Hasil Belajar IPS Melalui Model Pembelajaran Kooperatif Tipe Make A Match. WACANA AKADEMIKA: Majalah Ilmiah Kependidikan, 1(1), 1-12. https://doi.org/10.30738/wa.v1i1.998

Maryam, S., \& Sukmana, N. (2019). Penggunaan Model Make A Match Untuk Meningkatkan Pemahaman Konsep Ilmu. 2, 156-162.

Maryani, N., Ichsan, M., \& Khairunnisa. (2017). Signifikansi Metode Guide Reading Terhadap Motivasi Belajar Siswa Dalam Teori Membaca Nyaring Guide Reading Method On Students ' Learning Motivation In Reading Loudly Lesson. Didaktika Tauhidi: Jurnal Pendidikan Guru Sekolah Dasar, 4(2), 126-139. https://doi.org/http://dx.doi.org/10.30997/dt.v4i2.924

Mawardi, G., Iriani, T., \& Daryati. (2019). Pengembangan Media Pembelajaran Berbasis Multimedia Pada Mata Kuliah Kompetensi Pembelajaran Pokok Materi Keterampilan Dasar Mengajar. Jurnal Pendidikan Teknik Sipil, 8(1), 24-30.

Miskawati, M. (2019). Upaya Meningkatkan Kreativitas Anak Dalam Pembelajaran Seni Tari Melalui Strategi Belajar Sambil Bermain di TK Islam Sa'adatul Khidmah Tahun Pelajaran 2016/2017. Jurnal Ilmiah Dikdaya, 9(1), 45. https://doi.org/10.33087/dikdaya.v9i1.123

Nafotira, A. (n.d.). Peran Orang Tua dalam Mengembangkan Minat Baca Pada Anak Usia Sekolah Dasar Kelas 1 (Satu) di Surabaya. 1.

Nida, \& Dkk. (2020). Pengembangan Media Kartu Bergambar Berorientasi Pendidikan Karakter Pada Mata Pelajaran Bahasa Bali. Jurnal EDUTECH Universitas Pendidikan Ganesha., 8(1), 16-31. Retrieved from https://ejournal.undiksha.ac.id/index.php/JEU/article/view/25393/15846

Olivia, P., \& Dkk. (2019). Efektifitas Penggunaan Model Pembelajaran Make A Match Terhadap Perkembangan Interaksi Sosial Anak. Jurnal Pendidikan Anak., 5(1). 
Pane, A., \& Darwis Dasopang, M. (2017). Belajar Dan Pembelajaran. FITRAH:Jurnal Kajian Ilmu-Ilmu Keislaman, 3(2), 333. https://doi.org/10.24952/fitrah.v3i2.945

Puspitowati, P. (2019). Penerapan Model Pembelajaran Berbasis Pengalaman (Experiential Learning) dengan Menggunakan Media Gambar dalam Pembelajaran Menulis Karangan Deskripsi pada Siswa Kelas IV MI Riyadlatul Uqul. Linguista: Jurnal Ilmiah Bahasa, Sastra, Dan Pembelajarannya, 3(2), 120. https://doi.org/10.25273/linguista.v3i2.5734

Putri, \& Dkk. (2018). Pengaruh Model Pembelajaran PBL Berbantuan Media Gambar Terhadap Hasil Belajar IPA Siswa Kelas III SD. Jurnal Mimbar Ilmu, 23(1), 53-64. Retrieved from https://ejournal.undiksha.ac.id/index.php/MI/article/view/16407/9826

Riyanti, \& Nisrohah. (2018). Penerapan Model Pembelajaran Kooperatif Tipe Make A Matchuntuk Meningkatkan Hasil Belajar IPS. Jurnal Penelitian Pendidikan Guru Sekolah Dasar, 6(4), 440-450.

Rohaeti, E. E., Ramadan, B. G., \& Fitriani, N. (2019). Cognitive Stage Relation with Creative Thinking Ability and Mathematical Learning Interests. Journal of Physics: Conference Series, 1315(1). https://doi.org/10.1088/1742-6596/1315/1/012079

Salma, \& Mudzanatun. (2019). Analisis Gerakan Literasi Sekolah Terhadap Minat Baca Siswa Siswa Sekolah Dasar. Mimbar PGSD Undiksha, 7(2), 122-127.

Samsi, yogi setia. (2015). (Printed) ISSN 2598-3202 (Online) ISSN 2599-316X. Kredo, 2, 338-350. https://doi.org/ISSN 2598-3202

Saputro, L. (2019). Pengaruh Penggunaan Media Gambar Terhdap Hasil Belajar Siswa Kelas IV. Jurnal Ilmu Pendidikan, 19(1), 37-43.

Sujana, I. W. C. (2019). Fungsi Dan Tujuan Pendidikan Indonesia. Adi Widya: Jurnal Pendidikan Dasar, 4(1), 29. https://doi.org/10.25078/aw.v4i1.927

Susanti. (2020). The Use of WhatsApp in Reading Lesson at the STMIK Pontianak, West Kalimantan, Indonesia. Mimbar Pendidikan, 5(1), 57-74. Retrieved from https://ejournal.upi.edu/index.php/mimbardik/article/view/24151/11694.

Tiballa, Meida, \& Dkk. (2017). Pengaruh Model Pembelajaran Kooperatif Tipe Make a Match Berbantuan Peta Pikiran Trhadap Hasil Belajar IPA Siswa Kelas V Sekolah Dasar. Mimbar PGSD Undiksha, 5(2), $1-10$.

Tiswardini, D. (2019). Seminar Nasional Bahasa dan Sastra Indonesia Sasindo Unpam. Proceedings, 1(2), 141-146.

Ubaidah, N. (2016). Pemanfaatan CD Pembelajaran untuk Meningkatkan Kemampuan Komunikasi Matematis Siswa melalui Pembelajaran Make a Match. Jurnal Pendidikan Matematika FKIP Unissula, 4(1), 5370.

Umbara, D. (2020). Model Pembelajaran Problem Based Learning Berbantuan Media Gambar Seri BerpengaruhTerhadap Kompetensi Pengetahuan IPS Siswa. Jurnal Mimbar Ilmu, 25(2), 174-186. Retrieved from https://ejournal.undiksha.ac.id/index.php/MI/article/view/25154/15610

Visual, M. (2012). ( P ) -ISSN 2354-6948 ( E ) -ISSN 2580-4855 Peningkatan Hasil Belajar ... Ishartutik. 6948, 22-27.

Widodo, S., \& Kartikasari, K. (2017). Pembelajaran Pemecahan Masalah Matematis Siswa Sekolah Dasar Dengan Model Creative Problem Solving (Cps). Prisma, 6(1). https://doi.org/10.35194/jp.v6i1.28

Wirasasmita, \& Hendriawan. (2020). Analisis Efisiensi Kinerja Pendidik terhadap Hasil Pembelajaran Pendidikan Jasmani pada Siswa Sekolah. Mimbar Pendidikan, 5(1), 75-90.

Yuliana, D., Ratu, N., Matematika, P., Kristen, U., \& Wacana, S. (2020). Analisis Keterampilan Dasar Visual Geometri Siswa Smp Ditinjau Berdasarkan Level Berpikir Analisis. 03(02), 536-549.

Yuswanti. (2019). Pengunaan Media Gambar Untuk Meningkatkan Hasil Belajar Siswa Pada Pembelajaran IPS Di Kelas IV SD PT. Lestari Tani Teladan (LTT) Kabupaten Donggala. Jurnal Kreatif Tadulako, 3(4), 185-199. 